Вищеназвані зауваження та міркування носять радше рекомендаційний характер. Вони ніяк не знижують безперечних і цінних здобутків монографії Володимира Газіна «Між Москвою та Варшавою. «Українське питання» у 1654-1667 рр.», яка $\epsilon$ оригінальним і самостійним дослідженням і розв'язує важливу наукову проблему. Монографія Володимира Газіна, без сумніву, є вагомим дослідницьким доробком і значним внеском в історіографію історії Української революції XVII ст. Безперечно, книга буде цікавою історикам-фахівцям, педагогам і всім, хто цікавиться історією України.

\title{
ДОЛАЮЧИ СТЕРЕОТИПИ
}

[рец.]: Маслійчук В.Л. Здобутки та ілюзії. Культурно-освітні ініціативи на Лівобережній та Слобідській Україні другої половини XVIII - першої третини XIX ст. Харків: Харківський приватний музей міської садиби, 2018. 540 с.

\section{Олександр Лук'яненко}

Полтавський національний педагогічний університет ім. В.Г. Короленка (Полтава, Україна) e-mail: lukyanenko.ov@gmail.com

ORCID: https://orcid.org/0000-0002-6228-6695

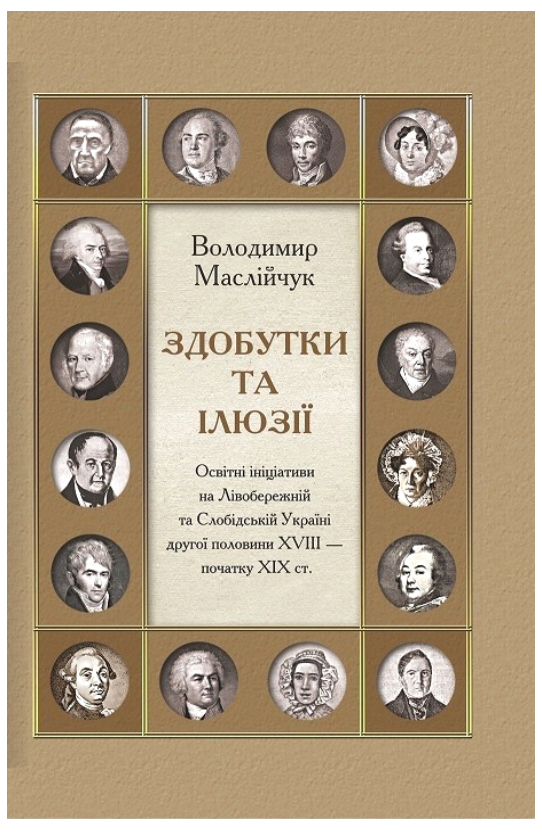

Історія культури й освіти $€$ одним із пріоритетів сучасних гуманітарних досліджень. Поява нового детального дослідження 3 історії виникнення та функціонування навчальних закладів на досить великій території українських земель у складі Російської імперії одразу привертає увагу, а прочитання змушує робити паралелі та порівняння з сучасними проблемами в освіті.

Плюсом даної монографії є спроба поєднати освітні процеси в Україні із ширшими загальноєвропейськими змінами, що отримали назву «освітньої революції» - появи системи шкіл і вищих навчальних закладів, якими опікується держава. У даному разі 3 постання нового університету, мережі шкіл в адміністративних центрах, допуск жінок до освіти - процеси суголосні як щодо Західної Європи, так і Північної Америки.

Монографія складається зі вступу, п’яти розділів і висновків. Книжка містить спи- 
ски ілюстрацій, джерел і літератури, географічний та іменний покажчики, англомовну анотацію. Це багато ілюстрована не лише наукова, але за обширом матеріалу і досить пізнавальна робота, що висвітлює тематику освіти, займається постановкою питань і насичена новим джерельним матеріалом.

Після короткого вступу, де обгрунтовується потреба у даному дослідженні, хронологічні та географічні рамки (від початку гетьманства Кирила Розумовського до змін у російському Міністерстві освіти 1817 р.) Володимир Маслійчук у першому розділі знайомить читача з історіографією питання й основними джерелами з українських і російських архівів. Доведення необхідності таких досліджень необхідне, бо оформлення сучасної шкільної системи має своє коріння передусім у студійованих науковцем проектах, у здійснених задумах та відкритих установах.

Починаючи другий розділ «Лівобережна Україна від Розумовського до Миклашевського», Автор спиняється на тій освітньо-культурній моделі, що вже існувала на українських землях - парафіяльних школах і православних колегіумах. Соціокультурна характеристика, здійснена дослідником, констатує, що ідеалізовані попередніми істориками колегіумське навчання та дяківська школа не відповідали потребам світської держави та підпадали під секуляризаційні процеси. Історик у даному розділі дещо порушує визнані хронологічні рамки, констатує коріння проблем більш раннього часу, ще до Духовного регламенту 1722 р. Але у висвітленні культурних процесів узагалі важко дотримуватися певної хронології. Автор досить детально зупиняється на освітніх стратегіях доби гетьманства Кирила Розумовського і до нього: освітні подорожі дітей значних козацьких старшин за кордон, навчання у російських столицях, особливо у Кадетському корпусі. Слід визнати важливий момент, побіжно згаданий автором: освіта (особливо у Кадетському корпусі) поєднувала у собі західні впливи на формування шляхетства як такого, надавала «культурний капітал» для кар'єри у подальшому1.

Одне з основних питань, що підіймає дослідник, - секуляризація та зміни в освіті у зв'язку з конфіскацією у церкви майна. Доба Розумовського, попри проекти і заклики, запровадження нововведень лубенським полковником Іваном Кулябкою, залишається часом ілюзійних проектів. Серед нереалізованих проектів було відкриття університету в Батурині й училищ у великих центрах. Подальшу історію нездійснених до 80-х рр. XVIII ст. освітніх планів у Гетьманщині Володимир Маслійчук пояснює «культурним консерватизмом» місцевої еліти, яка, попри гучні проекти, прагнула дотримуватися старих звичаїв і залишалася вірною усталеним способам отримання освіти.

Третій розділ: «Світський освітній експеримент на Слобідській Україні» відображає важливе питання причин і передумови відкриття імперською владою університету у Харкові на початку XIX ст. Автор вбачає кілька причин: своєрідність церковного життя (суперечності Білгородської єпархії з українською та російською частинами), слабкість консерватизму та певна відкритість до новацій у регіоні (особливо у середовищі місцевого шляхетства), i, найголовніше, - успіх світських навчальних ініціатив, що виявилися у Харківських додаткових класах (училищі), навчального закладу, що з певними змінами існував з 1768 р. до перетворення на гімназію у 1806 р. Це новаторський розділ, що частково заперечує усталену думку про роль

\footnotetext{
${ }^{1}$ Fedyukin I., Gabdrakhmanov S. Cultural Capital and Education in St. Petersburg: The Noble Cadet Corps 1732-1762 // Journal of Interdisciplinary History. 2016. Vol. 46. Issue 4. P. 485-516.
} 
громадськості у постанні майбутнього університету. Уже після виходу рецензованої книжки світ побачила робота Володимира Склокіна про взаємовідносини Слобідської України з імперським центром, що певною мірою доповнює рецензовану працю та вносить корективи у розумінні імперської політики².

Четвертий розділ розповідає про хід «училищної реформи»: запровадження училищ в основних губернських і повітових центрах у 1789-1796 рр. Автор детально розкриває процес «освітньої революції» у Чернігівському та Новгород-Сіверському, а з використанням нових джерел, й у Київському намісництвах. Свіжий погляд науковця характеризує і підрозділ про «створення соціальної альтернативи» у відкритті училищ уже наприкінці 90-х pp. XVIII ст. Історик аналізує спроби влади опертися не на шляхетство, а на купців і міщан у справі відкриття та підтримки училищ у Ромні та Погарі. У Слобідській Україні успіх «училищної реформи» був очевидним і значно відчутнішим, аніж на Лівобережжі, не лише через обставини існування вже світського навчального закладу, але й завдяки особистій ініціативі місцевого просвітителя Івана Переверзєва.

Найоб'ємнішим є п’ятий розділ «Поблизу і на віддалі від університету. Слобідська та Лівобережна Україна: основні зміни в освіті 1802-1818 рр.». Тут найрозлогіше висвітлено регіональну диспропорцію в освітній сфері, пояснено, чому Харків і Слобідсько-Українська губернія випереджали за кількістю закладів сусідні Чернігівську та Полтавську губернії, описано, як відкриття жіночих закладів мало на меті станове обмеження, що не давало доступу до освіти представницям нешляхетного походження. Основним завданням розділу, вочевидь, є аналіз проведення і наслідків реформи освіти за часів імператора Олександра I. Автор подає важливі ремарки не лише щодо реформ і нововведень, а загалом щодо історії освіти, яка далеко не завжди демонструвала рух по висхідній, а нерідко переживала кризові часи. В. Маслійчук висвітлює суперечності щодо виникнення та функціонування навчальних закладів, притаманні і сучасній українській школі: слабкий матеріальний стан, невисока якість освіти, низька престижність учительської праці.

Висновки Володимира Маслійчука долають стереотипи та вводять історію досліджуваних ним земель у світовий контекст. Автор наголошує, що саме по собі становлення світської освіти не було однозначним і часто було повільним процесом, поєднаним зі значним змінами у культурі. Тож епоха Просвітництва, особливо на сході Європи, у контексті його роздумів не може мати однозначних оцінок.

Окремі твердження Володимира Маслійчука є дискусійними. Передусім йдеться про спростування уже сталих історіографічних тверджень, на які дослідник начебто не «звертає уваги». Наприклад, про високий рівень освіти у колегіумах чи значну роль Харківського колегіуму у постанні Харківського університету, або ж про високий рівень освіченості жінок з вищих прошарків суспільства у XVIII ст. Можливо, дані питання потребували б окремого розгляду. Так само можна охарактеризувати висвітлення істориком ролі вищих прошарків суспільства у становленні системи освіти. У випадках окремих ідеалізованих постатей у сфері освіти, зокрема, гетьмана Кирила Розумовського чи родини Полетик (Григорія та Василя), дослідник, на відміну від попередніх істориків, займає досить скептичну позицію, пишучи про риторичні заяви нереалізовані на практиці. Але тут можна посперечатися щодо Григорія Полети-

\footnotetext{
2 Склокін В.В. Російська імперія і Слобідська Україна у другій половині XVIII ст.: просвічений абсолютизм, імперська інтеграція, локальне суспільство. Львів: УКУ. 2019. 238 с.
} 
ки. Можливо, його проекти і мали слабку адміністративну підтримку в Україні, та Г. Полетика був одним із основних творців навчальної системи у Морському кадетському корпусі в імперській столиці у 60-х рp. XVIII ст. 3

Під час прочитання даної праці вловимий особистий скепсис Автора і внесення особистого, а не відстороненого, бачення тих чи тих проблем, із наголошенням «позитивів», з «виправданнями», чи навпаки «засудженням» окремих історичних постатей. Але, дане зауваження характерне для більшості сучасних історичних праць. У деяких випадках були б доцільні порівняння не лише з досвідом в освітній сфері у сусідніх Австрійській і Прусській державах, але й в інших провінціях і губерніях Російської імперії. Особливо цікавими, у даному разі, виявляються балтійські провінції 3 німецькомовним дворянством та ідеалізацією селянського світу4 ширило б розуміння Просвітництва у Центрально-Східній Європі.У даній монографії помітні й невеликі огріхи, передусім друкарські помилки, але вони є радше технічними, що не впливає на високу оцінку видання.

\section{REFERENCES}

Rudnev, D. (2015). Grigorii Andreevich Poletika i ego pedagogicheskaia deiatelnost [Grigory Andreevich Poletika and his pedagogical activity]. In: «Reguliarnaia akademiia uchrezhdena budet...». Obrazovatelnye proekty $v$ Rossii $v$ pervoi polovine XVIII v. (Novye materialy i issledovaniia po istorii russkoi kultury) (pp. 363-400). Moskva: Novoe izdatelstvo [in Russian].

Sklokin, V.V. (2019). Rosiiska imperiia i Slobidska Ukraina u druhii polovyni XVIII st.: prosvichenyi absoliutyzm, imperska intehratsiia, lokalne suspilstvo [The Russian Empire and Slobidska Ukraine in the Second Half of the 18 ${ }^{\text {th }}$ Century: Enlightened Absolutism, Imperial Integration, and Local Society]. Lviv: UKU [in Ukrainian].

Daija, P. (2017). Literary History and Popular Enlightenment in Latvian Culture. Camdridge: Cambridge Scholars Publishing.

Fedyukin, I. \& Gabdrakhmanov, S. (2016). Cultural Capital and Education in St. Petersburg: The Noble Cadet Corps 1732-1762. Journal of Interdisciplinary History, 46/4, 485-516.

\footnotetext{
3 Руднев Д. Григорий Андреевич Полетика и его педагогическая деятельность // «Регулярная академия учреждена будет...». Образовательные проекты в России в первой половине XVIII в. (Новые материалы и исследования по истории русской культуры). Москва: Новое издательство, 2015. C. 363-400.

4 Daija P. Literary History and Popular Enlightenment in Latvian Culture. Camdridge: Cambridge Scholars Publishing. 2017. P. 31-32.
} 